\title{
Effect of surface roughness on the initial response of MC3T3-E1 cells cultured on polished titanium alloy
}

\author{
Chunya Wu $\mathrm{u}^{\mathrm{a},{ }^{*}, \text { Mingjun Chen }}{ }^{\mathrm{a}}$, Ting Zheng ${ }^{\mathrm{b}}$ and Xiaonan Yang ${ }^{\mathrm{c}}$ \\ ${ }^{a}$ State Key Laboratory of Robotics and System, Harbin Institute of Technology, Harbin, Heilongjiang \\ 150001, China \\ ${ }^{\mathrm{b}}$ School of Mechatronics Engineering, Harbin Institute of Technology, Harbin, Heilongjiang 150001, \\ China \\ ${ }^{\mathrm{c}}$ State Key Laboratory of Urban Water Resource and Environment, Harbin Institute of Technology, \\ Harbin, Heilongjiang 150090, China
}

\begin{abstract}
Surface roughness has been considered as an important influencing factor for cell response. The aim of this study was to find out whether MC3T3-E1 cells, a mouse osteoblast-like cell line, can sense the amplitudes of surface topography of titanium alloy (Ti6Al4V), and if surface-dependent cell morphology would be presented on the substrata with varied roughness. A series of polished samples $\left(\mathrm{R}_{\mathrm{a}}: 0.30 \sim 1.80 \mu \mathrm{m}\right)$ were prepared to produce macroscopically parallel grooves using different grades of silicon carbide sandpaper (\#100, \#320, \#600, \#1000 and \#2000). The experimental results indicated that the behavior and morphology of cells largely depended on the substrata where they were cultured. More efficient proliferation of MC3T3-E1 cells was shown on the surfaces with $\mathrm{R}_{\mathrm{a}}$ of $0.50 \sim 1.00 \mu \mathrm{m}$, with respect to either the rougher or the smoother specimens. Furthermore, MC3T3-E1 cells seeded on the Ti6A14V surfaces within this narrow range responded to the increasing surface roughness with increased proliferation. Contact guidance of cells could be observed on the rougher specimens $\left(\mathrm{R}_{\mathrm{a}}: 0.80 \sim 1.00 \mu \mathrm{m}\right)$, whereas more random orientations were exhibited for the adsorbed cells on the smoother surfaces $\left(\mathrm{R}_{\mathrm{a}}: 0.50 \sim 0.60 \mu \mathrm{m}\right)$.
\end{abstract}

Keywords: Cell morphology, cell proliferation, surface topography, contact guidance

\section{Introduction}

The early cell-biomaterial interplay, which largely depends on the topography, chemistry, mechanical properties, and surface energy of materials, exerts a strong influence on the clinical success of implants. Among varied surface characteristics of substrata, topographical features at the micro-scale are known to be able to affect adhesion, morphology, migration and orientation of cells, as well as the expression of genes [1,2]. The topographical characteristics of the material with dimensions in the same order as the cell microenvironment are of paramount importance in

\footnotetext{
* Address for correspondence: Chunya Wu, State Key Laboratory of Robotics and System, Harbin Institute of Technology, Harbin, Heilongjiang 150001, China. Tel.: +86 451 86403252; Fax: +86 451 86403252; E-mail: wuchunya1982@163.com.
}

0959-2989/15/\$35.00 @ 2015 - IOS Press and the authors. 
influencing the initial attachment of cell, which may induce changes in cell shape [3]. The changes in cell shape are subsequently transduced through the cytoskeleton to the nucleus, where a change in gene expression is likely to be generated $[4,5]$.

Cell responses to the topographical geometries of surfaces of the materials commonly used in orthopaedic applications have been widely studied using cultured bone-derived cells [6-11]. Overall, the currently available studies can be broadly divided into two groups. One aims to determine the general trend for cell adhesion and proliferation onto the substrate surfaces with a variety of magnitudes of roughness, whereas the other focuses to explore the effect of well-defined or precisely machined structures (e.g., microgrooves or microchannels) on the cellular behaviors. Chesmel et al. [12] found that the bone cells oriented randomly on smooth surfaces but lined up parallel to the grooves with a depth of $5 \mathrm{~mm}$, whereas the topography on a $0.50 \mathrm{~mm}$-deep grooved surface was "ignored" by the cells. Anselme's results [13] indicated that the cultured human osteoblasts "preferred" grooved Ti surfaces with a relatively high micro-roughness amplitude and a low level of repeatability. The initial cell-substrate interaction $(30 \mathrm{~min} \sim 24 \mathrm{~h}$ ) revealed that U2OS cells attached more readily to rougher Ti surfaces than to smoother ones [14]. On the other hand, Ball, et al. [15] concluded that cells on the ordered surfaces could spread or elongate fully, while the shape of cells on the rough surfaces was constrained to a great extent. Lee, et al. [9] observed that for the cells in serum solution with a concentration of $4 \%$, the attachment of rat osteoblasts on the smooth polished Ti6Al4V and HA coating surfaces was significantly higher than that on the rough surfaces.

From the above results, it can be found that the overall effect of surface topographies on the initial cell behaviors still keeps unclear. A complete understanding of how metabolic activities of cells, in terms of attachment, adhesion, spreading, and proliferation, vary with the topographical features presented on the surface of biomaterials is necessary to be approached, which will be helpful to foreknow the contribution of surface topography of a given material to its biocompatibility. The investigations conducted in this work were focused on the question if MC3T3-E1 cells, a mouse osteoblast-like cell line, can sense the amplitudes of surface topography of Ti6Al4V specimens, and whether apparently diverse cell morphologies would be exhibited on the substrata with a variety of roughness. We anticipate that the findings presented here will ultimately contribute to improving the biological performance of biomedical products, by suggesting how to tailor the surface topography of biomaterials to promote attachment and spreading of anchorage-dependent cells.

\section{Materials and methods}

\subsection{Surface preparation and roughness measurement}

Discs of titanium alloy (Ti6Al4V, chemical composition: $6 \%$ aluminium, $4 \%$ vanadium, $0.25 \%$ (maximum) iron, $0.2 \%$ (maximum) oxygen, and the remainder titanium), $10 \mathrm{~mm}$ in diameter and 1 $\mathrm{mm}$ in height, were processed by polishing with different grades of silicon carbide paper (\#100, \#320, $\# 600$, \#1000 and \#2000). Surface roughness of Ti6A14V samples is quantified by $R_{a}$, which is the arithmetic average of the absolute values of the profile height deviations from the mean line, recorded within the evaluation length. In this study, six individual measurements of surface roughness were performed on each sample using a confocal laser scanning microscope (OLS3000, Olympus Corporation) with the dimension of scanning area equal to $65 \times 65 \mu \mathrm{m}^{2}$. The data of surface roughness reported below are the mean values of six measurements. Metallic substrata were ultrasonically cleaned with acetone for once, $75 \%$ ethanol for once and demineralized water for three times, before 
sterilization by steam for cell culture.

\subsection{Cell culture}

A mouse osteoblast-like cell line (MC3T3-E1) was initially cultured in a Dulbecco's modified essential medium (DMEM), supplemented with $10 \%$ fetal calf serum, 100 units $/ \mathrm{ml}$ of penicillin and $100 \mu \mathrm{g} / \mathrm{ml}$ of streptomycin, at $37^{\circ} \mathrm{C}, 5 \% \mathrm{CO}_{2}$ atmosphere and $100 \%$ humidity in an incubator (Thermo Electron Corporation). The confluent cells were harvested using trypsin-EDTA and inoculated onto Ti6A14V samples in 24-well plates. The MC3T3-E1 cells with the same density were also cultured directly in a single well of the plate (i.e., a polystyrene surface) as the control group. The medium was changed every two days.

\subsection{MTT assay}

In the proliferation tests of MC3T3-E1, the unattached cells and the culture medium were removed first after five incubation periods: $4 \mathrm{~h}, 1 \mathrm{~d}, 3 \mathrm{~d}, 5 \mathrm{~d}$ and $7 \mathrm{~d}$, respectively. The samples were washed with phosphate-buffered saline (PBS), and the cells were subsequently incubated with tetrazolium salt solution (MTT), 3-[4, 5-dimethylthiozol-2-yl]-2, 5-diphenyltetrazolium bromide for $4 \mathrm{~h}$ in a standard tissue culture environment, as described above $\left(37^{\circ} \mathrm{C}, 5 \% \mathrm{CO}_{2}, 100 \%\right.$ humidity). The MTT was reduced to an insoluble formazan precipitate by mitochondrial succinic dehydrogenase of viable cells, and then dimethylsulfoxide (DMSO) was added to each well after the removal of culture medium to completely dissolve the blue crystal of MTT formazan. Optical density (OD) of the dissolved solute was measured by means of enzyme linked immunosorbent assay (ELISA) under a light source with the wavelength of $492 \mathrm{~nm}$.

\subsection{Scanning electron microscopy}

To visualize the morphology of MC3T3-E1 cells under a scanning electron microscope (SEM, FEI Quanta 200), the samples covered with cell layers were washed with PBS, and then fixed with a prewarmed fixative, containing glutaraldehyde, paraformal-dehyde and phosphate buffer, $\mathrm{pH}$ 7.20. After fixation, the samples were rinsed with PBS again, and subsequently dehydrated in graded ethanol series successively $(30 \%, 50 \%, 70 \%, 80 \%, 90 \%$, and $100 \%)$. Finally, the absolute ethanol in which the dehydration was performed twice was replaced by acetonitrile. The samples were critical-point dried under $\mathrm{CO}_{2}$ (Emitech, K850), and a thin layer of Au was sputter-coated (BAL-TEC, SCD 005 Sputter Coater) onto the surfaces prior to SEM examination.

\subsection{Crystal violet staining}

To gain the morphology of MC3T3-E1 cells using a digital microscope (Keyence, VHX-1000E), the samples after cell seeding were washed twice with PBS, and then the cells were incubated with PBS containing $2.5 \%$ glutaraldehyde for 30 minutes at room temperature. After the above steps, the cells were stained with $1 \%$ crystal violet solution for 20 minutes $\left(25^{\circ} \mathrm{C}\right)$, and subsequently washed with deionized water gently. Finally, simply allow the stained cells to dry at room temperature before microscope observation. 


\section{Results and discussions}

\subsection{Surface characterization}

Schwartz, et al. [16] believed that the topographical characteristics of materials with dimensions in the same order as the cell microenvironment had the greatest influence on the metabolic activities of cells. They postulated that the macro-architecture in the context of individual cell could be defined as any morphologic feature that was greater than the cell itself [16]. Thus, a structured surface with a relatively low $R_{a}$ value, which is in the dimension of one cell's microenvironment, may affect cell parameters to a greater extent than surfaces with a higher $R_{a}$ [17]. The average size of an osteoblast is about 20 25 $\mu \mathrm{m}$, then a roughness greater than the length of cell would be perceived as smooth by the cells locating between the adjacent peaks [18]. Hence, the polished Ti6Al4V discs with surface roughness in a specific range were selected to find out whether the MC3T3-E1 cells would sense the surface topography of Ti alloy in the dimension of cell's microenvironment. The classification of samples is listed in Table 1 . All the samples with $R_{a}$ in the range of $0.30 \sim 1.80 \mu \mathrm{m}$ were classified as series 1 , which was divided into five subranges to split the samples into group $\mathrm{I} \sim \mathrm{V}$. Figure 1 shows the surface topography of typical metallic specimens, which indicates that the produced roughness consists of macroscopically parallel longitudinal grooves and ridges. Compared to the smooth surface, the specimen with a larger value of $\mathrm{R}_{\mathrm{a}}$ features more significant groove and ridge morphology.

\subsection{Cell proliferation}

In addition to the polystyrene culture plate, MC3T3-E1 cells were inoculated onto $15 \mathrm{Ti}$ alloy samples within each roughness range with a cell-seeding concentration of $1.4 \times 10^{5}$ cells/well. The proliferation of cells was evaluated by measuring the OD values via MTT assay after $4 \mathrm{~h}, 1 \mathrm{~d}, 3 \mathrm{~d}, 5 \mathrm{~d}$

Table 1

Classification of the polished Ti6Al4V samples

\begin{tabular}{llll}
\hline series 1 & & series 2 & \\
\hline group ID & $\mathrm{R}_{\mathrm{a}}(\mu \mathrm{m})$ & group ID & $\mathrm{R}_{\mathrm{a}}(\mu \mathrm{m})$ \\
I & $0.30 \sim 0.50$ & $\mathrm{~A}$ & $0.50 \sim 0.60$ \\
II & $0.50 \sim 0.70$ & $\mathrm{~B}$ & $0.60 \sim 0.70$ \\
III & $0.70 \sim 1.00$ & $\mathrm{C}$ & $0.70 \sim 0.80$ \\
IV & $1.00 \sim 1.20$ & $\mathrm{D}$ & $0.80 \sim 1.00$ \\
V & $1.20 \sim 1.80$ & control & - \\
control & - & & \\
\hline
\end{tabular}
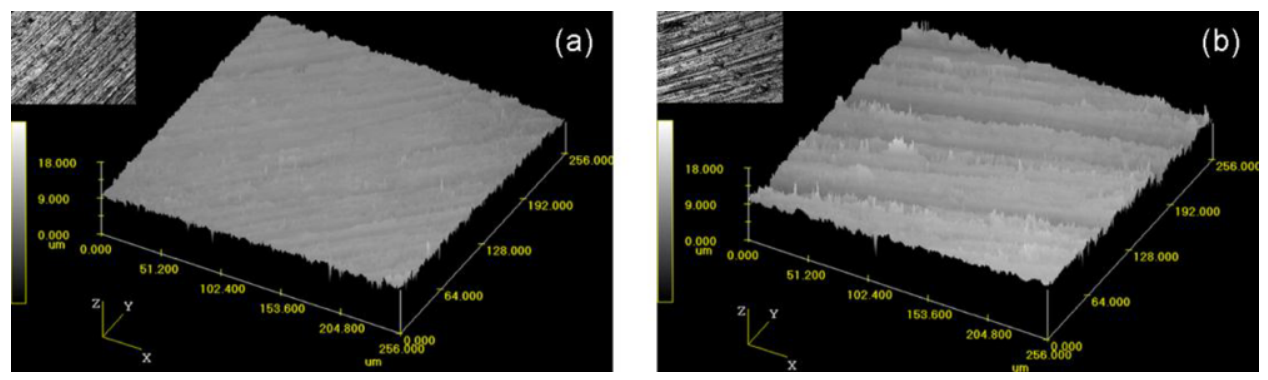

Fig. 1. Surface topographies of Ti6Al4V specimens after SiC sandpaper polishing. (a) $R_{a}=0.38 \mu \mathrm{m}$; (b) $R_{a}=0.82 \mu \mathrm{m}$. 


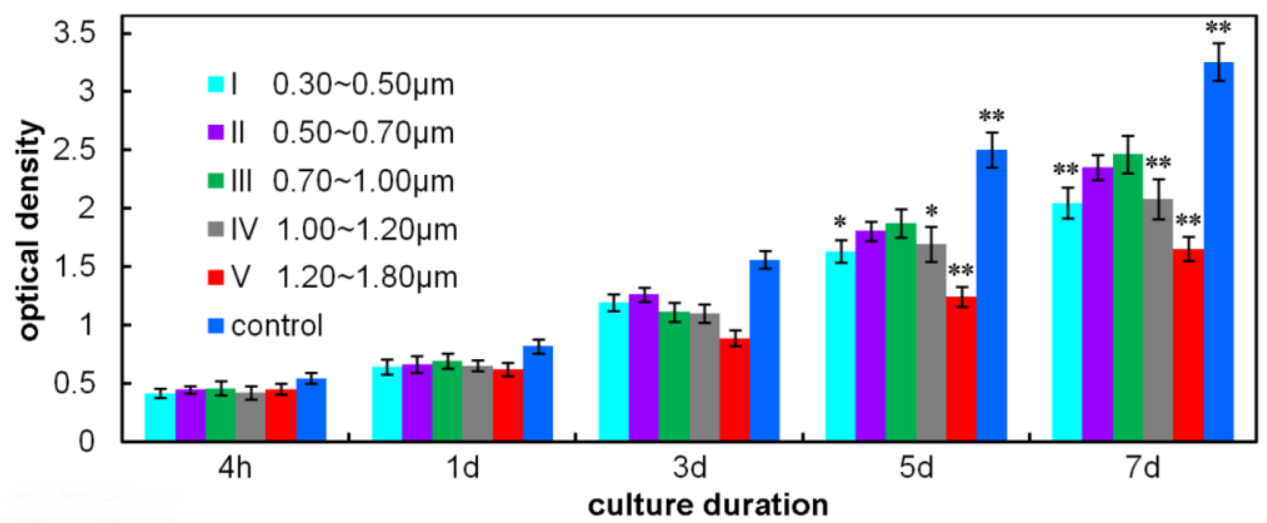

Fig. 2. Optical density for MC3T3-E1 cells cultured on polished Ti6Al4V specimens with increasing surface roughness. ${ }^{*} p$ $<0.05, * * p<0.01$ ( $v s$. group III).

and $7 \mathrm{~d}$ of culture, respectively. That is, testing under the same condition was run in triplicate and the data mentioned below are mean values of the three parallel samples. Figure 2 shows the OD values for MC3T3-E1 cells on Ti6A14V surfaces with increasing roughness. An analysis of variance (ANOVA) is performed to test the significant differences between OD values for MC3T3-E1 cells cultured on surfaces with different roughness. The ANOVA results of the proliferation rate further indicates that roughness is an important influencing factor in MC3T3-E1 proliferation. The proliferative activity of MC3T3-E1 cells increased as the surface roughness increased, when the value of $R_{a}$ was lower than $1.00 \mu \mathrm{m}$. However, once the roughness exceeded the critical point $(1.00 \mu \mathrm{m})$, MC3T3-E1 cells exhibited a less activated proliferation, which may be attributed to the existing topographical feature. That is, too many irregularities presented on the rough surface may make the cell hard to form enough number of stable contacts with the substrate.

In the case of fetal rat calvarial cells, a similar trend in proliferation on a smooth and another four rough surfaces $\left(\mathrm{R}_{\mathrm{a}}: 0.37,0.81,1.70,2.90 \mu \mathrm{m}\right)$ was also reported [19], indicating the optimum average roughness of $0.81 \mu \mathrm{m}$. Deligianni, et al. [20] found that the number of adherent human bone marrow cells per surface unit of Ti alloy increased with the increase of surface roughness in a narrow scope $\left(\mathrm{R}_{\mathrm{a}}\right.$ : $0.32,0.49$ and $0.87 \mu \mathrm{m})$. However, the OD value of osteoblast-like U2OS cells on ground Ti specimens decreased in response to surface roughness $\left(\mathrm{R}_{\mathrm{a}}: 0.15 \sim 1.20 \mu \mathrm{m}\right)$ [21]. Bigerelle, et al. [22] examined the effect of roughness organization of Ti6Al4V or pure titanium substrata on human osteoblast response and claimed that when the surface roughness was much smaller than the dimension of cell, the smooth surface would be appreciated. Although a consensus on the correlation between surface roughness and initial cellular functions has not been reached in the currently available literatures, the cells seem to be sensitive to the micro-scale environment of the anchoring surface. The present inconsistency might be explained by the differences in cell species, substrata materials, and/or the methods by which the surface features were fabricated.

\subsection{Cell morphology}

The overall distribution of cells after crystal violet staining was observed under a digital microscope. As shown in Figure 3, the cells on the rough surface after 1d incubation were inclined to be oriented along the direction of groove, whereas the cells on the smooth surface after $4 \mathrm{~h}$ incubation seemed to disperse widely in all directions. It appears that the cellular response to surface roughness was indeed 

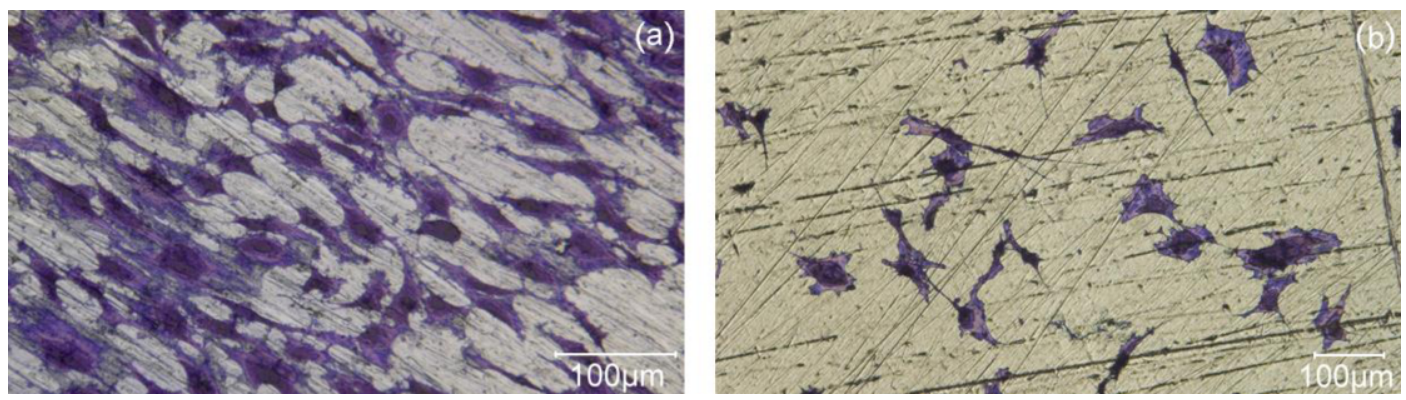

Fig. 3. Micrographs of crystal violet stained cell. (a) $\mathrm{R}_{\mathrm{a}}=0.85 \mu \mathrm{m}$ (after $1 \mathrm{~d}$ incubation); (b) $\mathrm{R}_{\mathrm{a}}=0.35 \mu \mathrm{m}$ (after $4 \mathrm{~h}$ incubation).

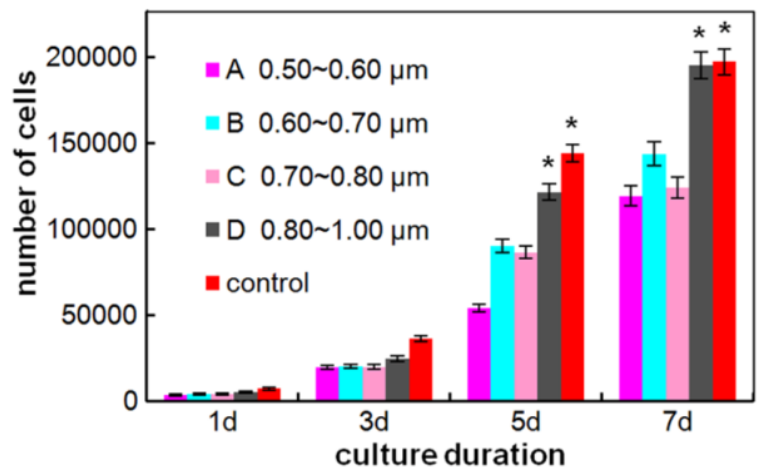

Fig. 4. Proliferation curves for cells on polished Ti6Al4V surfaces as a function of culture duration. ${ }^{*} p<0.05$ ( $v s$. group A).

affected by the topographical features in the micrometer scale. To further investigate the role of surface topography in cell-substrate interaction, samples with $\mathrm{R}_{\mathrm{a}}$ of $0.50 \sim 1.00 \mu \mathrm{m}$ were selected and classified as series 2 (see Table 1), since the above analysis indicated that MC3T3-E1 cells reacted more actively to roughness within this range than to roughness at a higher or lower scale, notably after 5 days of culture. The surface range of $R_{a}=0.50 \sim 1.00 \mu \mathrm{m}$ was divided into four subranges to split the samples into group A D. An extensive coverage of cells was reached on each sample after 1d incubation in the above experiments; thus a lower cell-seeding concentration $\left(5 \times 10^{3}\right.$ cells/well $)$ was selected to ensure that individual cells could be observed by SEM at early time points.

As shown in Figure 4, the proliferation of MC3T3-E1 cells increases as a function of time, particularly on the rough surface $\left(\mathrm{R}_{\mathrm{a}}: 0.80 \sim 1.00 \mu \mathrm{m}\right)$. There is no significant difference in the number of MC3T3-E1 cells per sample on different surfaces after 1d incubation. The proliferative activities of cells on group $B\left(R_{a}: 0.60 \sim 0.70 \mu \mathrm{m}\right)$ and $C\left(R_{a}: 0.70 \sim 0.80 \mu \mathrm{m}\right)$ after $3 d$ and $5 d$ incubation are almost identical, whereas the number of cells on the rough surface $\left(\mathrm{R}_{\mathrm{a}}: 0.80 \sim 1.00 \mu \mathrm{m}\right)$ is obviously larger than that on the smooth surface $\left(\mathrm{R}_{\mathrm{a}}: 0.50 \sim 0.60 \mu \mathrm{m}\right)$, indicating that MC3T3-E1 cells prefer surfaces with a relatively high amplitude of micro-roughness. After $7 \mathrm{~d}$ incubation, the number of cells on the rough surface (density: 2486.8 cells $/ \mathrm{mm}^{2}$ ) is almost equal to the control surface (density: 1033.8 cells $/ \mathrm{mm}^{2}$ ). The differences in cell density showed above arises from two factors. One is that the diameter of control surface (the diameter of wells in the polystyrene plates: $15.6 \mathrm{~mm}$ ) is larger than the diameter of the presented Ti6Al4V discs; the other is that the polystyrene surface of plate itself is more excellent for the cells than the titanium alloy. Therefore, the cells on the control surface presents a much plumper shape than the ones on the Ti6Al4V surface, resulting in a larger area occupies by each plump cell, thereby a relatively lower cell density. The tendency of increasing cell proliferation 
begins to slow down after $7 \mathrm{~d}$ incubation on all the surfaces except the smoothest one, which might provide a clue that the cells on the control and three rougher surfaces were nearly confluent, competing for the growing space, whereas the cells on the smooth surface kept proliferating with a relatively weak effect of density suppression, as a result of an insufficient confluence of cells.

Individual cells were examined by SEM for each sample and visible morphological differences between cells growing on the surfaces in group $\mathrm{B}$ and $\mathrm{C}$ were hard to distinguish in the present experiments. Hence, the typical morphology of cells cultured on the surface with $\mathrm{R}_{\mathrm{a}}$ of $0.80 \sim 1.00 \mu \mathrm{m}$ were chosen to be compared with that on the surfaces with $\mathrm{R}_{\mathrm{a}}$ of $0.50 \sim 0.60 \mu \mathrm{m}$. Since the density of cells increased significantly with the extension of time, the complete cell perimeter was hard to be identified at later time points as a result of the excessively close contact of cells with each other. Moreover, it was also difficult to distinguish the cells from the surface, because the confluent cell layer masked the residual machining traces and looked as if it was a part of the surface roughness. Due to these reasons, the cells after $1 \mathrm{~d} \sim 3 \mathrm{~d}$ incubation were selected to be shown in the following SEM images.

The cells on the rough surface (Figure 5) were oriented along the groove with little lateral spreading, keeping compact with only thin actin filaments, in agreement with Chesmel's results [12]. The enlarged cell in Figure 5(b) was especially notable, presenting a fusiform morphology and looking as if it had "fallen into the crack" on the surface, which could be referred to as "contact guidance". Although cell response is cell-type dependent, this morphological aspect accords well with the phenomenon of rat fibroblasts cultured on the micro-grooved $\mathrm{Ti}$ substrata, where the cells needed grooves with a minimal width of $10 \mu \mathrm{m}$ to reach the floor of the grooves [23]. Also, MC3T3-E1 cells on the textured Ti6Al4V surfaces with 8 or $12 \mu \mathrm{m}$ deep grooves were observed to undergo contact guidance and limited cell spreading [24]. On the contrary, the cells on the smooth surface had a very intimate contact with the substrata through abundant filopodia. As shown in Figure 6(a), they dispersed widely in all directions, exhibiting disordered orientations. That is, the cells could align with the surface in different ways in response to surface topographies, which can possibly be explained by Anselme's hypothesis that the cells may tend to find a favorable state to balance the internal and external forces [13]. From Figures 6(b) and 6(c), it can be observed that the cells on smooth surface showed a flattened, well-spread appearance with an organized filamentous actin network. A similar phenomenon was also observed in Linez-Bataillon's experiments [25] that more the surface of Ti6A14V was smooth more the MC3T3 osteoblasts appeared spread out on the test samples. After 2d or 3d incubation, the MC3T3-E1 cells cultured on the smooth surface still showed random orientation
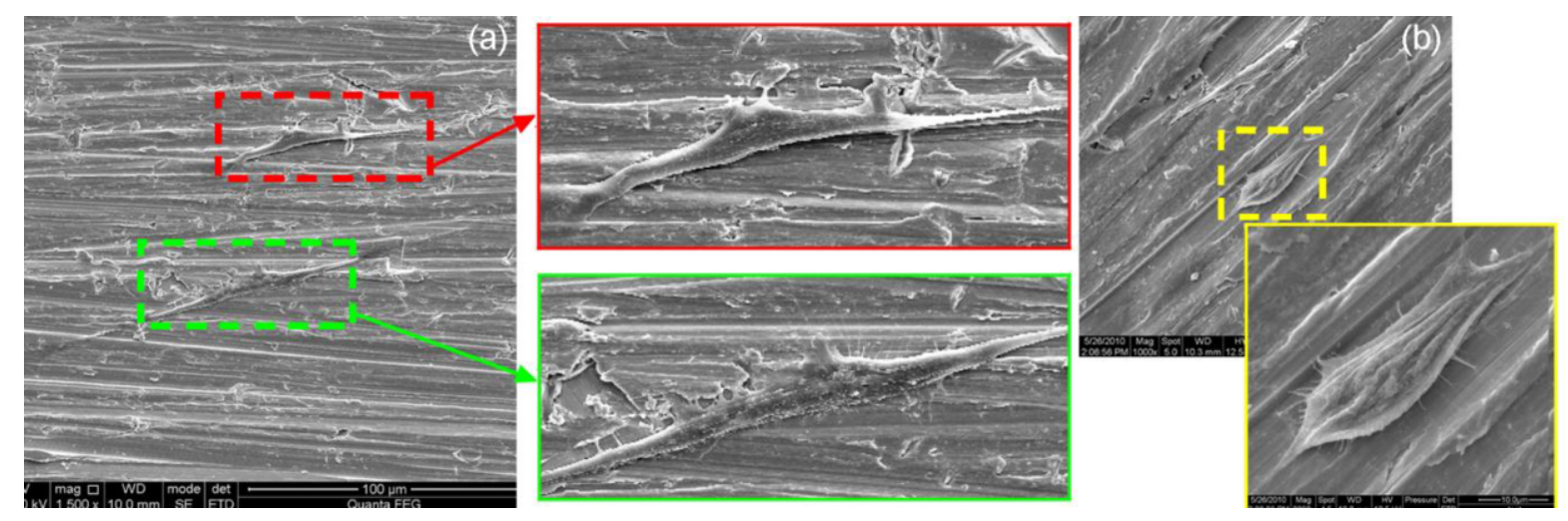

Fig. 5. Scanning electron micrographs of MC3T3-E1 cells cultured on polished Ti6A14V specimens with $\mathrm{R}_{\mathrm{a}}$ of $0.80 \sim 1.00 \mu \mathrm{m}$. (a) After 1d incubation; (b) After 2d incubation. 

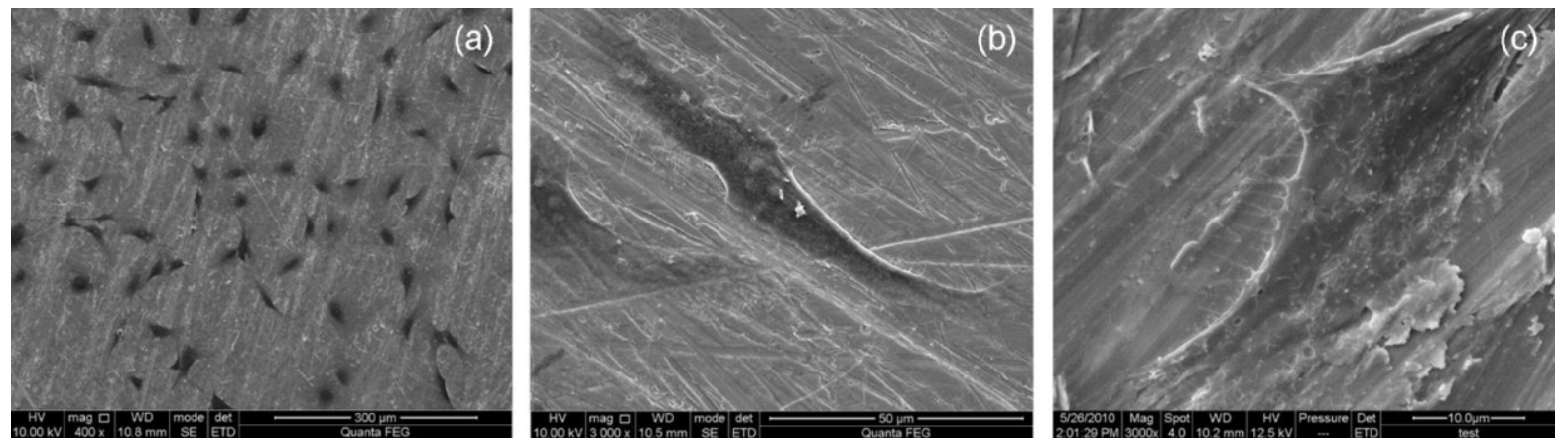

Fig. 6. Scanning electron micrographs of MC3T3-E1 cells cultured on polished Ti6A14V specimens with $\mathrm{R}_{\mathrm{a}}$ of $0.50 \sim 0.60 \mu \mathrm{m}$ after 1d incubation. (a) Cells in large scale; (b) Single cell A; (c) Single cell B.
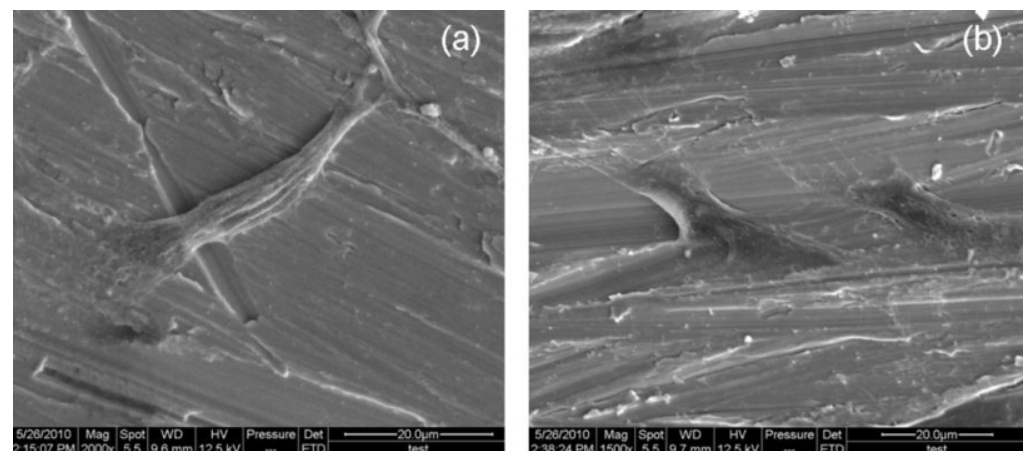

Fig. 7. Scanning electron micrographs of MC3T3-E1 cells cultured on polished Ti6Al4V specimens with $\mathrm{R}_{\mathrm{a}}$ of $0.50 \sim 0.60 \mu \mathrm{m}$. (a) After 2d incubation; (b) After 3d incubation.

and the boundaries of adjoining cells began to fuse with each other. Part of the cells on the smooth surface (Figure 7) bridged the groove, scratching the ridges with the attaching ends, which may be attributed to the width of groove (too small to contain an individual cell). This phenomenon agrees with Walboomers's results to a certain extent that rat dermal fibroblasts on the narrowest and deepest microgrooves bridged the grooves, due to the absence of direct contact between cells and the floor of grooves [26].

The differences in the morphologies of cells cultured on the rough and smooth surfaces may be explained from two aspects. In terms of surface geometry, the higher ridges and lower valleys on the rough surface may exert stronger constraints on the spreading of cells; thus the cells will be inclined to lie along the groove with little lateral spreading. On the contrary, the shallow grooves on the smooth surface only impose weak restraints on the cells; thus the cells keep an intimate contact with the substrata, showing a flattened, well-spread morphology. In terms of cell activity, it is unnecessary for the cells supported by ridges and pitches to express a distinctive actin network, whereas the ones on a smooth surface have to spread and develop a strong actin network in order to stabilize themselves on the surface.

\section{Conclusions}

Mouse osteoblast-like cells response in variation with surface roughness of polished Ti6Al4V discs 
were investigated to find out whether surface topographies can be sensed by the MC3T3-E1 cells, leading to an alteration in early cell-biomaterial interplay. The results of present study indicated that surface roughness $\left(\mathrm{R}_{\mathrm{a}}: 0.30 \sim 1.80 \mu \mathrm{m}\right)$ might be a key factor in determining the morphological and functional cell responses. The MC3T3-E1 cells exhibited a less activated proliferation when the surface roughness was considered above the critical point $\left(\mathrm{R}_{\mathrm{a}}=1.00 \mu \mathrm{m}\right)$. However, when the surface roughness was considered below the critical point, the MC3T3-E1 cells responded positively to roughness in a narrower range $\left(\mathrm{R}_{\mathrm{a}}: 0.50 \sim 1.00 \mu \mathrm{m}\right)$, appreciating the rough surface.

The cells on the smoother surface $\left(\mathrm{R}_{\mathrm{a}}: 0.50 \sim 0.60 \mu \mathrm{m}\right)$ dispersed widely in all directions, showing a flattened, well-spread appearance with an organized filamentous actin network. On the contrary, the cells on the rough surface were oriented along the direction of the groove, keeping more compact and less-spread with thin actin filaments. The different alignments of cells with the substrata in response to various surface topographies may be related to the hypothesis from Anselme [13] that the cells may tend to find a favorable state to balance the internal and external forces. The higher ridges and lower valleys on the rough surface may exert stronger constraints on the cells, whereas the shallow grooves on the smooth surface can only impose weak restraints; thus the cells on the smooth surface try to spread widely, developing a strong actin network to stabilize themselves on the substrata.

Different surfaces of substrata in this work were distinguished by the term "roughness", which does little to describe the local micro-/nano-structures, thus it is impossible to require exactly identical cell morphologies being presented on the surfaces with similar roughness. That is, the researches in this field should not concentrate solely on the magnitude of surfaces roughness, but also need to take into account the role of local micro-/nano-geometrical characteristics in directing cell responses. However, the information provided here, indicating the optimum average roughness of $0.80 \sim 1.00 \mu \mathrm{m}$, may serve as a reference in the development of bone contacting devices, which are capable of accelerating earlier osseointegration in clinical application using any material other than titanium alloy.

\section{Acknowledgments}

This work was supported by National Natural Science Foundation of China (No. 51201050), the State Key Laboratory of Robotics and System, Harbin Institute of Technology (No. SKLRS-2015-MS04), and the Fundamental Research Funds for the Central Universities.

\section{References}

[1] R.G. Flemming, C.J. Murphy, G.A. Abrams, S.L. Goodman and P.F. Nealey, Effects of synthetic micro- and nanostructured surfaces on cell behavior, Biomaterials 20 (1999), 573-578.

[2] B. Groessner-Schreiber and R.S. Tuan, Enhanced extracellular-matrix production and mineralization by osteoblasts cultured on titanium surfaces in vitro, Journal of Cell Science 101 (1992), 209-217.

[3] G. Gronowicz and M.B. McCarthy, Response of human osteoblasts to implant materials: Integrin-mediated adhesion, Journal of Orthopaedic Research 14 (1996), 878-887.

[4] S.K. Akiyama, Integrins in cell adhesion and signaling, Human Cell: Official Journal of Human Cell Research Society 9 (1996), 181-186.

[5] M.E. Chicurel, R.H. Singer and C.J. Meyer, Integrin binding and mechanical tension induce movement of mRNA and ribosomes to focal adhesion, Nature 392 (1998), 730-733.

[6] C. Larsson, L. Emanuelsson, P. Thomsen, L.E. Erison, B.O. Aronsson, B. Kasemo and J. Lausmaa, Bone response to surface modified titanium implants-studies on the tissue response after 1 year to machined and electropolished implants with different oxide thicknesses, Journal of Materials Science: Materials in Medicine 8 (1997), 721-729.

[7] Q.F. Zan, C. Wang, L.M. Dong, P. Cheng and J.M. Tian, Effect of surface roughness of chitosan-based microspheres on 
cell adhesion, Applied Surface Science 55 (2008), 401-403.

[8] L.L. Zhang, H.J. Li, K.Z. Li, J.H. Lu, X.T. Shen and F.T. Lan, MG63 osteoblast-like cells response of SiC coating for carbon/carbon composites, Surface Review and Letters 16 (2009), 683-687.

[9] T.M. Lee, R.S. Tsai, E. Chang, C.Y. Yang and M.R. Yang, The cell attachment and morphology of neonatal rat calvarial osteoblasts on the surface of Ti-6Al-4V and plasma-sprayed HA coating: Effect of surface roughness and serum contents, Journal of Materials Science: Materials in Medicine 13 (2002), 341-350.

[10] M.H. Lee, N. Oh, S.W. Lee, J.H. Kang and S.C. Lee, Enhancement of dynamic wettability, cell adhesion, and alkaline phosphatase activity of primary cells on titanium substrata with combined surface topographies of microgrooves and acid-etched roughness, Tissue Engineering and Regenerative Medicine 7 (2010), 501-512.

[11]S. Makihira, Y. Mine, E. Kosaka and H. Nikawa, Titanium surface roughness accelerates RANKL-dependent differentiation in the osteoclast precursor cell line, RAW264.7, Dental Materials Journal 26 (2007), 739-746.

[12] K.D. Chesmel, C.C. Clark and C.T. Brighton, Cellular responses to chemical and morphologic aspects of biomaterial surfaces. II. The biosynthetic and migratory response of bone cell populations, Journal of Biomedical Materials Research 29 (1995), 1101-1110.

[13]K. Anselme, M. Bigerelle, B. Noël, A. Iost and P. Hardouin, Effect of grooved titanium substratum on human osteoblastic cell growth, Journal of Biomedical Materials Research 60 (2002), 529-540.

[14] P.J. der Brugge, S. Dieudonne and J.A. Jansen, Initial interaction of U2OS cells with noncoated and calcium phosphate coated titanium substrates, Journal of Biomedical Materials Research 61 (2002), 399-407.

[15]M. Ball, D.M. Grant, W.J. Lo and C.A. Scotchford, The effect of different surface morphology and roughness on osteoblast-like cells, Journal of Biomedical Materials Research-Part A 86A (2008), 637-647.

[16]Z. Schwartz, C.H. Lohmann, J. Oefinger and L.F. Bonewald, Implant surface characteristics modulate differentiation behavior of cells in the osteoblastic lineage, Advances in Dental Research 13 (1999), 38-48.

[17]F. Lüthen, R. Lange, P. Becker, J. Rychly and U. Beck, The influence of surface roughness of titanium on $\beta 1$ - and $\beta 3$ integrin adhesion and the organization of fibronectin in human osteoblastic cells, Biomaterials 26 (2005), 2423-2440.

[18]D.M. Brunette, Spreading and orientation of epithelial cells on grooved substrata, Experimental Cell Research 167 (1986), 203-217.

[19] K. Hatano, H. Inoue, T. Kojo, T. Matsunaga, T. Tsujisawa, C. Uchiyama and Y. Uchida, Effect of surface roughness on proliferation and alkaline phosphatase expression of rat calvarial cells cultured on polystyrene, Bone 25 (1999), 439-445.

[20]D.D. Deligianni, N. Katsala, S. Ladas, D. Sotiropoulou and J. Amedee, Effect of surface roughness of the titanium alloy Ti-6Al-4V on human bone marrow cell response and on protein adsorption, Biomaterials 22 (2001), 1241-1251.

[21] H.H. Huang, C.T. Ho, T.H. Lee, T.L. Lee, K.K. Liao and F.L. Chen, Effect of surface roughness of ground titanium on initial cell adhesion, Biomolecular Engineering 21 (2004), 93-97.

[22] M. Bigerelle, K. Anselme, B. Noël, I. Ruderman, P. Hardouin and A. Iost, Improvement in the morphology of Ti-based surfaces: A new process to increase in vitro human osteoblast response, Biomaterials 23 (2002), 1563-1574.

[23]E.T. Den Braber, H.V. Jansen and M.J. de Boer, Scanning electron microscopic, transmission electron microscopic, and confocal laser scanning microscopic observation of fibroblasts cultured on microgrooved surfaces of bulk titanium substrata, Journal of Biomedical Materials Research 40 (1998), 425-433.

[24] W. O. Soboyejo, B. Nemetski, S. Allameh, N. Marcantonio, C. Mercer and J. Ricci, Interactions between MC3T3-E1 cells and textured Ti6A14V surfaces, Journal of Biomedical Materials Research 62 (2002), 56-72.

[25]P. Linez-Bataillon, F. Monchau, M. Bigerelle and H.F. Hildebrand, In vitro MC3T3 osteoblast adhesion with respect to surface roughness of Ti6A14V substrates, Biomolecular Engineering 19 (2002), 133-141.

[26] X.F. Walboomers, W. Monaghan, A.S. Curtis and J.A. Jansen, Attachment of fibroblasts on smooth and microgrooved polystyrene, Journal of Biomedical Materials Research 46 (1999), 212-231. 